\title{
Pengembangan Kemampuan Pemecahan Masalah Matematis melalui Habit of Thinking Interdependently
}

\author{
Fevi Rahmadeni
}

Insitut Agama Islam Negeri (IAIN) Curup

fevirahmadeni@iaincurup.ac.id

\begin{tabular}{l}
\hline \hline Article Info \\
\hline Article history: \\
Received April $12^{\text {th }}, 2020$ \\
Revised April $23^{\text {th }}, 2020$ \\
Accepted May $10^{\text {th }}, 2020$
\end{tabular}

Keywords:

Problem Solving Ability;

Habit of Thinking

Interdependently

Kata Kunci:

Kemampuan Pemecahan Masalah Matematis; Habit of Thinking Interdependently
Abstract

Like the human body, problem solving is the heart of mathematics. Problem solving ability is a capital for students to develop and explore themselves further in mathematics learning. This article aim to explain the development of students' mathematical problem solving abilities through Habit of Thinking Interdependently (HTI). This type of research is literature review where the authors analyze and draw conclusions from several relevant references related to HTI. HTI the attitude of students towards learning mathematics in the form of the habit of thinking together in groups. The conclusions obtained indicate that students' mathematical problem solving abilities can be developed through HTI.

Abstrak
Ibarat tubuh manusia, pemecahan masalah merupakan
jantungnya matematika. Kemampuan pemecahan
masalah adalah modal bagi siswa untuk berkembang dan
mengeksplor diri lebih jauh dalam pembelajaran
matematika. Tujuan penulisan artikel ini adalah
menjelaskan pengembangan kemampuan pemecahan
masalah matematis siswa melalui Habit of Thinking
Interdependently (HTI). Penelitian ini termasuk jenis
Penelitian Studi Pustaka (Library Research), dimana
penulis menganalisis dan menarik kesimpulan terhadap
beberapa referensi relevan terkait HTI. HTI merupakan
sikap siswa terhadap pembelajaran matematika berupa
kebiasaan berpikir bersama dalam kelompok.
Kesimpulan yang diperoleh menunjukkan bahwa
kemampuan pemecahan masalah matematis siswa dapat
dikembangkan melalui HTI.
jantungnya matematika. Kemampuan pemecahan masalah adalah modal bagi siswa untuk berkembang dan mengeksplor diri lebih jauh dalam pembelajaran matematika. Tujuan penulisan artikel ini adalah menjelaskan pengembangan kemampuan pemecahan masalah matematis siswa melalui Habit of Thinking Interdependently (HTI). Penelitian ini termasuk jenis Penelitian Studi Pustaka (Library Research), dimana penulis menganalisis dan menarik kesimpulan terhadap beberapa referensi relevan terkait HTI. HTI merupakan sikap siswa terhadap pembelajaran matematika berupa kebiasaan berpikir bersama dalam kelompok. Kesimpulan yang diperoleh menunjukkan bahwa dikembangkan melalui HTI. 


\section{PENDAHULUAN}

Tujuan pendidikan sekolah setiap negara adalah mengembangkan kemandirian, percaya diri, berpikir kritis, motivasi dan menjadi individu multitalenta yang akan mengelola berbagai lingkungan sosial berbeda yang akan mereka temui dalam hidup mereka di kemudian hari (Pehkonen, 2007). Pertanyaannya adalah upaya apa yang dapat dilakukan untuk tujuan ini? Cooney (dalam Hendriana \& Soemarmo, 2014). Hiebert et al. (1996) mengungkapkan bahwa kepemilikan kemampuan pemecahan masalah dapat membantu siswa berpikir analitik dalam mengambil keputusan di kehidupan sehari-hari dan membantu meningkatkan kemampuan berpikir kritis dalam menghadapi situasi baru. Kegiatan pemecahan masalah memberikan siswa kesempatan untuk menghadapi kesulitan yang dapat ia atasi dengan memanfaatkan kombinasi pengetahuan yang dimilikinya (deklaratif, prosedural, dan kondisional) secara efisien dalam konteks yang terdefinisi dengan baik (Caprioara, 2014). Berdasarkan beberapa uraian tersebut, pengembangan kemampuan pemecahan masalah matematis siswa merupakan salah satu hal yang dapat dilakukan untuk mencapai tujuan tersebut.

Perlunya pengembangan kemampuan pemecahan masalah bagi siswa juga dikemukakan oleh Dede dalam Kim (2019) yang menyatakan bahwa beberapa kemampuan siswa yang perlu dikembangkan di abad 21 adalah kemampuan pemecahan masalah, berpikir kritis, kreativitas, metakognisi, digital dan teknologi, serta tanggung jawab. Di dalam matematika, pemecahan masalah merupakan konsep yang paling efektif untuk kontekstualisasi dan re-kontekstualisasi konsep, transfer pengetahuan matematika dasar dan operasional untuk memastikan pembelajaran yang berkelanjutan dan bermakna. Berbagai manfaat dari kepemilikan kemampuan pemecahan masalah, mulai dari manfaat bagi siswa di kehidupan sehari-hari hingga di bidang akademik sendiri menunjukkan bahwa kemampuan pemecahan masalah sebagai kemampuan yang sangat penting untuk dimiliki siswa.

Berbicara tentang matematika, pembelajaran matematika di sekolah tak akan pernah luput dari persoalan matematika mulai dari persoalan sederhana sampai pada persoalan kompleks, persoalan rutin yang sering 
ditemui oleh siswa sampai pada persoalan non rutin yang tidak biasa siswa temui sebelumnya. Kemampuan siswa dalam menyelesaikan permasalahan non rutin inilah yang disebut kemampuan pemecahan masalah matematis. Dikategorikan sebagai soal pemecahan masalah salah satu cirinya adalah jika siswa tidak segera langsung dapat menemukan jawaban dalam sekali langkah penyelesaian, namun harus melalui beberapa langkah lain yang relevan. Karena bukan merupakan soal yang rutin ditemui siswa, maka soal pemecahan masalah merupakan soal yang menantang untuk diselesaikan.

Sayangnya, pentingnya kemampuan pemecahan masalah, tak sejalan dengan apa yang terjadi pada kenyataannya. Sebagaimana pernyataan Stanick dan Kilpatrick (1989) bahwa masalah telah menduduki tempat utama dalam kurikulum matematika sekolah sejak zaman dahulu tetapi tidak demikian dengan pemecahan masalah. Indikasinya adalah indeks prestasi kemampuan pemecahan masalah matematis siswa masih rendah. Penelitian mengenai kemampuan pemecahan masalah matematis juga menunjukkan hasil yang belum memuaskan. Penelitian Akbar dkk (2018) mengenai analisis kesalahan yang dilakukan siswa dalam mengerjakan soal matematika di salah satu sekolah di Indonesia menunjukkan bahwa persentase yang dicapai siswa untuk indikator memahami masalah hanya mencapai $48,75 \%$ (rendah), merencanakan penyelesaian $40 \%$ (rendah), menyelesaikan masalah 7,5\% (sangat rendah), dan melakukan pengecekan 0\% (sangat rendah). Hasil yang kurang memuaskan juga diperoleh Ninik dkk (2014) di mana persentase untuk indikator memahami masalah, membuat rencana penyelesaian, melaksanakan rencana penyelesaian, dan menelaah kembali tergolong rendah.

Berdasarkan beberapa permasalahan yang telah dipaparkan di atas kemampuan pemecahan masalah matematis siswa perlu mendapat perhatian lebih dan dikaji lebih jauh upaya pengembangannya dalam diri siswa. Pemecahan masalah merupakan proses kompleks yang memerlukan individu untuk mengkoordinasikan pengalaman yang telah dimiliki sebelumnya, pengetahuan matematika, pemahaman, dan intuisi agar dapat menyelesaikan permasalahan (Charles, 1987). Artinya, agar 
4| Rahmadeni : Pengembangan Kemampuan Pemecahan Masalah Matematis ...

dapat menyelesaikan permasalahan yang ada siswa dituntut untuk berpikir lebih kritis dan tajam terhadap apa yang diketahui dan ditanyakan soal, serta jalan penyelesaian apa yang dapat digunakan untuk memecahkan masalah. Sebagaimana ujaran Krulick \& Rudnick (1989) bahwa pemecahan masalah terdiri dari serangkaian proses berpikir untuk membentuk heuristik berupa pertanyaan dan saran yang menuntun siswa menemukan solusi atas permasalahan yang dihadapi. Oleh karenanya, membangun dan melatih kebiasaan berpikir merupakan upaya yang dapat dilakukan untuk meningkatkan kemampuan pemecahan masalah. Salah satu dari enam belas macam kebiasaan berpikir adalah habit of thinking interdependently (HTI). HTI merupakan kebiasaan berpikir secara bersama-sama dengan orang lain dan mengambil kesimpulan dari berbagai macam asumsi yang muncul dalam pembelajaran kelompok.

Pembelajaran kelompok memfasilitasi siswa untuk mengembangkan HTI. Melalui iklim pembelajaran kooperatif yang baik, siswa dapat saling bertukar pikiran dalam menyelesaikan permasalahan yang diberikan, menarik kesimpulan dari berbagai macam asumsi yang muncul, menarik ide pokok dari beragam pendapat yang dipaparkan, lebih jauh lagi akan muncul beragam cara penyelesaian untuk mendapatkan jawaban dari soal yang diberikan yang belum tentu terpikirkan oleh masing-masing individu. Oleh karenanya, HTI dianggap dapat memberikan pengaruh positif bagi peningkatan kemampuan pemecahan masalah matematis siswa.

Penelitian tentang analisis HTI dalam pembelajaran matematika telah dilakukan (Huda, 2016). Begitu pun penelitian tentang upaya peningkatan kemampuan pemecahan masalah matematis melalui metode pembelajaran tertentu (Effendi dalam Ulvah \& Efriansyah, 2016) juga telah ada. Akan tetapi penelitian mengenai upaya pengembangan kemampuan pemecahan masalah melalui pemaksimalan kebiasaan berpikir siswa berupa HTI belum dilakukan. Studi pustaka ini dilakukan untuk melihat pengembangan kemampuan pemecahan masalah matematis siswa melalui HTI. 


\section{METODE PENELITIAN}

Artikel ini merupakan sebuah studi pustaka (literature review). Studi pustaka yang dilakukan yakni dengan mengumpulkan beberapa referensi terkait HTI dan kemampuan pemecahan masalah matematis siswa. Referensi tersebut kemudian dibaca dan dianalisis untuk memperoleh informasi mengenai HTI dan kemampuan pemecahan masalah matematis siswa. Selanjutnya dilakukan penarikan kesimpulan mengenai pengembangan kemampuan pemecahan masalah matematis siswa melalui HTI.

\section{HASIL PENELITIAN DAN PEMBAHASAN}

Garofalo dan Lester (dalam Kaur, 1997) menyatakan pemecahan masalah sebagai proses yang melibatkan visualisasi, asosiasi, abstraksi, pemahaman, manipulasi, penalaran, analisis, sintesis, generalisasi dimana masing-masing perlu dikelola dan semua harus dikoordinasikan. Lebih lanjut lagi, Charles (1987) mengungkapkan bahwa pemecahan masalah melibatkan penarikan kembali fakta, penggunaan berbagai keterampilan dan prosedur, kemampuan untuk mengevaluasi pemikiran dan kemajuan seseorang sembari memecahkan masalah, dan banyak kemampuan lainnya. Begitu kompleksnya sebuah proses pemecahan masalah menuntut siswa memiliki berbagai kompetensi yang relevan untuk dapat menyelesaikan masalah. Jika kemampuan pemecahan masalah siswa belum maksimal, maka penyebabnya pasti karena salah satu atau beberapa aspek yang terlibat dalam proses pemecahan masalah belum dimiliki siswa secara maksimal.

Salah satu aspek penting yang diperlukan dalam proses pemecahan masalah adalah kemampuan berpikir siswa. Sebagaimana pernyataan Charles (1987) bahwa di dalam proses pemecahan masalah terdapat beberapa kemampuan berpikir yang penting dimiliki siswa di antaranya memahami atau memformulasikan pertanyaan pada masalah, memahami kondisi dan variabel apa saja yang terdapat pada masalah, memilih dan menentukan data yang dibutuhkan untuk memecahkan masalah, menentukan strategi penyelesaian yang tepat, mengimplementasikan 
6| Rahmadeni : Pengembangan Kemampuan Pemecahan Masalah Matematis ...

strategi penyelesaian yang telah ditentukan, memeriksa kembali apakah jawaban yang diperoleh masuk akal.

Tugas pertama yang harus dilakukan ketika menyelesaikan sebuah masalah adalah memformulasikan atau memahami pertanyaan dari sebuah permasalahan. Untuk beberapa kasus, pertanyaan terkadang tersirat dari sebuah pernyataan. Memahami pertanyaan berarti melibatkan pemaknaan terhadap kata-kata yang terdapat dalam sebuah permasalahan. Kemudian lanjut pada proses memahami kondisi dan variabel yang terdapat dalam permasalahan. Misal dalam permasalahan yang dikemukakan oleh Charles (1987) berikut:

"Tom dan Sue melihat sejumlah ayam dan kambing. Jika dijumlahkan ayam dan kambing seluruhnya ada 18. Jumlah seluruh kaki ayam dan kambing seluruhnya adalah 52. Berapa masing-masing jumlah ayam dan kambing yang Tom dan Sue lihat?"

Kedua, pemecah masalah harus dapat menentukan variabel apa saja yang terdapat dalam masalah. Terdapat dua kondisi dalam permasalahan di atas, yakni jumlah keseluruhan hewan adalah 18 dan keseluruhan kaki hewan berjumlah 52. Ada dua variabel dalam permasalahan tersebut, yakni jumlah ayam dan jumlah kambing. Selama proses penentuan variabel, si pemecah masalah dapat dibantu dengan membuat model matematika, diagram atau gambar, maupun mendaftar beberapa variabel yang ada untuk menentukan masing-masing jumlah ayam dan kambing.

Dalam memecahkan masalah, si pemecah masalah juga harus mampu mengidentifikasi data, mengeliminasi data yang tidak diperlukan dalam memecahkan masalah, serta mengumpulkan dan menggunakan data dari berbagai sumber seperti gambar ataupun tabel. Proses pemilihan data ini berhubungan erat dengan proses memahami pertanyaan, variabel serta kondisi dalam suatu masalah. Proses menentukan strategi penyelesaian termasuk dalam fase perencanaan. Di sini pemecah masalah harus menentukan apakah ada sub-masalah atau sub-tujuan yang harus dipecahkan terlebih dahulu untuk mencapai penyelesaian akhir dari permasalahan yang diberikan. Setelah mendapatkan penyelesaian akhir, pemecah masalah harus bisa menentukan apakah jawaban yang diperoleh 
masuk akal. Dalam proses ini, pemecah masalah akan membaca kembali variabel, kondisi, serta pertanyaan dari permasalahan yang ada.

Berbicara mengenai kebiasaan berpikir yang menjadi salah satu aspek penting bagi kemampuan pemecahan masalah matematis, hasil penelitian Slavin (dalam Rusman, 2010) menunjukkan bahwa kemampuan kebiasaan berpikir dan bekerja bersama dalam kelompok dapat memenuhi kebutuhan siswa dalam berpikir kritis, mengembangkan kemampuan dalam memecahkan masalah dan mengintegrasikan pengetahuan dengan pengalaman. Sementara Sharan dan Shachar dalam Qudsy dan Fawaid (2012) menemukan bahwa siswa yang terlibat dalam situasi berpikir bersama dalam kelompok tidak hanya memperoleh hasil akademik yang lebih besar, namun juga dapat menciptakan interaksi yang lebih komunikatif dalam kelompok serta lebih terfokus pada masalah yang harus mereka selesaikan daripada mereka yang terlibat dalam metode pengajaran tradisional pada umumnya. Hal itu disebabkan karena siswa yang terlibat dalam situasi berpikir bersama dalam kelompok memiliki kesempatan yang lebih besar untuk mempraktikkan strategi kognitif yang lebih variatif yang pernah mereka dengar dari gurunya saat proses belajar mengajar di kelas. Artinya, interaksi yang terjadi dalam pembelajaran memicu siswa untuk lebih mengembangkan kemampuan diri dalam menyelesaikan berbagai permasalahan mulai dari yang mudah sampai pada permasalahan yang sulit dan tidak pernah siswa selesaikan sebelumnya.

Hal senada diungkapkan oleh King dalam Qudsy dan Fawaid (2012), di mana berdasarkan hasil penelitiannya ditemukan bahwa siswa yang tidak dilatih untuk mengembangkan kognisinya melalui interaksi dalam kelompok tidak mampu mengembangkan jawaban dalam ujian problem solving tertulis, sehingga ia menyarankan guru-guru untuk melatih siswanya dalam berinteraksi, berpikir, dan duduk bersama dalam kelompok sehingga dapat mengembangkan kemampuan mereka dalam memberikan penjelasan dan menyelesaikan masalah dengan lebih detail dan efektif.

Kebiasaan siswa untuk berpikir secara bersama, bekerja secara kolaboratif, berbagi ide dan pengalaman antara satu dengan yang lain, dan 
8 | Rahmadeni : Pengembangan Kemampuan Pemecahan Masalah Matematis ...

menumbuhkan lingkungan kerjasama yang positif disebut HTI (Vollrath, 2016). Charbonneau et al. (2009) mendefinisikan positive interdependence atau ketergantungan positif sebagai sikap saling bertanggung jawab dan berbagi seperangkat prinsip bersama-sama dengan orang lain, sedangkan HTI didefinisikan sebagai kemampuan siswa untuk belajar dari mereka yang tidak secara resmi memegang gelar sebagai seorang guru. Selanjutnya Rusman (2010) mendefinisikan prinsip positive interdependence atau ketergantungan positif yakni dalam pembelajaran kelompok keberhasilan penyelesaian tugas tergantung pada usaha yang dilakukan kelompok tersebut dan kinerja masing-masing anggota kelompok, sehingga semua anggota kelompok akan merasakan saling ketergantungan. Dari kedua pendapat tersebut, dapat disimpulkan bahwa HTI membentuk siswa menjadi pembelajar yang mandiri dan tidak bergantung sepenuhnya pada guru.

McGregor (2007) menyatakan bahwa kolaborasi yang berpusat pada penyelesaian masalah memberikan peluang yang sangat baik untuk mengembangkan keterampilan kognitif dan sosial seperti mengklarifikasi, mengeksplorasi, merasionalisasi, menjelaskan, mengelaborasi, mengeksplorasi, merundingkan, membenarkan, memprioritaskan, bernegosiasi dimana begitu penting untuk menyelesaikan masalah sosial maupun konseptual dalam pekerjaan di masa depan. Sejalan dengan pendapat tersebut, Silver (1985) menyatakan bahwa pembelajaran kelompok dapat menjadi salah satu pendekatan untuk mempelajari pemecahan masalah. Melalui forum diskusi kelompok, siswa dapat mengeluarkan ide dan gagasan, di mana ide dan gagasan tersebut bisa saja ditolak atau dipertahankan. Secara tidak langsung siswa dilatih untuk melakukan klarifikasi terhadap suatu pernyataan. Hal tersebut tentu dapat meningkatkan logika berfikir dan analisis siswa yang dibutuhkan dalam proses pemecahan masalah. Sebagaimana Polya dalam Silver (1985) mengungkapkan bahwa diskusi kelompok dapat menjadi instrumen untuk mengembangkan kemampuan pemecahan masalah siswa (Polya dalam Silver, 1985).

Beberapa metode yang dapat memfasilitasi perkembangan kemampuan siswa untuk berpikir secara interdependen menurut 
Charbonneau et al. (2009) diantaranya sikap guru, konfigurasi kelas, software computer, dan kerja kelompok. Jika dalam pembelajaran pada umumnya guru merupakan pusat pembelajaran, maka lain halnya pada pembelajaran yang menekankan HTI. Pembelajaran tidak akan dijalankan hanya dengan seorang guru. Untuk menerapkan iklim pembelajaran berbasis HTI, bicaralah dengan siswa di awal pembelajaran bahwa posisi guru bukanlah merupakan satu-satunya sumber belajar siswa. Selayaknya seorang siswa, guru bersikap sebagai seorang pembelajar yang dapat saling belajar satu sama lain dengan siswa dan memperoleh pengetahuan baru setiap harinya.

Aspek lain yang dapat mendukung atmosfir pembelajaran yang menekankan HTI adalah konfigurasi kelas. Dalam hal ini, konfigurasi yang dimaksud adalah susunan bangku siswa. Guru hendaknya mengkonfigurasikan susunan bangku siswa ke dalam bentuk yang dapat memfasilitiasi kegiatan diskusi siswa. Konfigurasi bangku yang menyerupai bentuk sepatu kuda atau menyerupai huruf U dirasa pas bagi siswa dalam melakukan diskusi kelas. Dengan konfigurasi bangku yang seperti ini, guru akan lebih leluasa membangun suasana diskusi yang hangat ketimbang susunan bangku formal yang selama ini diterapkan di sekolah-sekolah pada umumnya, dimana semua mata siswa terpusat pada guru di depan kelas. Dengan susunan bangku yang menyerupai huruf U, setiap siswa dapat menjadi pusat perhatian pada saat menyampaikan gagasan. Interaksi yang muncul melalui kontak mata antar siswa akan membuat setiap kata yang keluar dari siswa menjadi lebih tersampaikan kepada seluruh penghuni kelas. Ketika muncul pertanyaan dari siswa, guru dapat melemparnya pada siswa yang lain dan memberi kesempatan untuk menjawab. Terakhir, guru dapat memberi penegasan terhadap jawaban yang benar kepada siswa.

Selain itu, guru juga dapat membagi siswa ke dalam kelompokkelompok kecil yang terdiri dari dua sampai empat orang untuk menyelesaikan beberapa permasalahan. Setelah waktu diskusi kelompok berakhir, mintalah juru bicara masing-masing kelompok untuk menyampaikan hasil diskusi kelompok. Aktivitas siswa di papan tulis juga dapat mendukung diskusi kelas. Setelah menyeleaikan masalah yang 
diberikan, siswa dapat membagikan hasil penyelesaian masalah berdasarkan perspektif kelompok masing-masing. Bagaimanapun juga, guru harus mendorong siswa untuk memberikan umpan balik berupa tanggapan atau saran terhadap apa yang dipaparkan oleh kelompok lain. Ketika muncul ketidaksetujuan, maka siswa harus menyampaikannya secara sopan dan tetap menghargai apa yang telah disampaikan. Di akhir pembelajaran, siswa akan menyadari bahwa seluruh anggota kelas telah memberikan kontribusi bagi keberlangsungan pembelajaran di kelas.

Konfigurasi kelas sendiri berhubungan dengan aspek pendukung pengembangan HTI siswa yang lain, yakni kerja kelompok. Di dalam kerja kelompok, terjadi diskusi antar anggota kelompok sehingga siswa dapat saling bertukar pikiran satu sama lain, menarik kesimpulan dari berbagai gagasan yang muncul, menyanggah gagasan yang dirasa kurang tepat. Selain itu, akan timbul beragam langkah penyelesaian yang mungkin belum terpikirkan oleh siswa sebelumnya. Hal ini tentu akan memperkaya khasanah pengetahuan siswa. HTI menuntut siswa untuk selalu ikut serta andil dalam setiap tahapan pembelajaran. Tidak ada siswa yang sibuk dengan urusannya sendiri di dalam diskusi kelompok. Setiap siswa memberikan kontribusi bagi kemajuan kelompok. Kesimpulan kelompok merupakan generalisasi dari hasil pemikiran anggota kelompok. Pembelajaran yang diharapkan bukan pembelajaran yang hanya melibatkan satu atau dua anggota kelompok saja, namun, keaktifan semua anggota kelompok merupakan kunci utama dalam penerapan HTI. Jadi, HTI merupakan kebiasaan berpikir yang dapat dilatih dan dikembangkan di dalam pembelajaran kelompok.

Beberapa software computer yang berkaitan dengan pembelajaran juga merupakan salah satu aspek yang dapat memfasilitasi perkembangan HTI siswa. Misalnya penggunaan software yang mendukung keberlangsungan pembelajaran di luar kelas, yakni sejenis pertemuan online yang dapat diakses melalui komputer. Free conference call, webex meet, dan click meeting merupakan contohnya. Guru dapat menyampaikan penjelasan materi lalu siswa bertanya baik secara lisan maupun tulisan, seperti halnya pembelajaran biasa di kelas. Teknik lain yang dapat memotivasi HTI siswa adalah penugasan kelompok untuk 
pengerjaan proyek yang diselesaikan di luar kelas. Tugas ini membantu siswa mengenali potensi diri bagi kontribusi kelompok, memahami beragam perspektif, dan bertanggung jawab bagi pemenuhan komitmen kelompok.

\section{SIMPULAN}

Berdasarkan literatur yang telah dipaparkan di atas, dapat ditarik kesimpulan bahwa HTI atau kebiasaan berpikir bersama dalam kelompok dapat memfasilitasi siswa dalam mengembangkan kemampuan pemecahan masalah matematis. Pembelajaran kelompok yang marak digiatkan dalam pembelajaran matematika sekolah pun dapat menjadi sarana pembiasaan berpikir bersama atau HTI siswa sebagai salah satu upaya pengembangan kemampuan pemecahan masalah matematis. HTI dapat melatih siswa untuk mengeluarkan gagasan secara terbuka, memberikan alasan, menilai kebenaran suatu gagasan yang diutarakan siswa lain, dan akhirnya menentukan penyelesaian suatu permasalahan berdasarkan gagasan-gagasan yang diberikan anggota kelompok. Implikasinya bagi pembelajaran matematika adalah pengembangan kemampuan pemecahan masalah matematis dapat diupayakan melalui pemaksimalan HTI siswa. Dengan begitu diharapkan kemampuan pemecahan masalah matematis siswa semakin berkembang dan lebih baik dari sebelumnya.

\section{DAFTAR PUSTAKA}

Akbar, Padillah dkk. (2018). Analisis Kemampuan Pemecahan Masalah dan Disposisi Matematika Siswa Kelas XI SMA Putra Juang dalam Materi Peluang. Journal Cendekia: Jurnal Pendidikan Matematika, 2 (1), 144-153. Retrieved from https://jcup.org/index.php/cendekia/article/view/62

Caprioara, Daniela. (2014). Problem Solving-Purpose and Means of Learning Mathematics In School. Procedia Social and Behavioral Sciences, 191(2015), 1859-1864. Retrieved from 
https://www.researchgate.net/publication/282536141_Problem_Sol ving_Purpose_and_Means_of_Learning_Mathematics_in_School Charbonneau, et al. (2009). Developing Students' "Habits of Mind" in a Mathematics Program. Problems, Resources, and Issues in Mathematics Undergraduate Studies, 19(2), 105. Retrieved from https://www.sciencedirect.com/science/article/pii/S1877042815025 926

Charles, R. (1987). How to Evaluate Progress in Problem Solving. Reston, VA: National Council of Teachers of Mathematics Effendi, Leo Adhar. (2012). Pembelajaran Matematika dengan Metode Penemuan Terbimbing untuk Meningkatkan Kemampuan Representasi dan Pemecahan Masalah Matematis Siswa SMP. Jurnal Penelitian Pendidikan, 13(2), 1-9. Retrieved from http://jurnal.upi.edu/penelitian-pendidikan/view/1852/ pembelajaran-matematika-dengan-metode-penemuan-terbimbinguntuk-meningkatkan-kemampuan-representasi-dan-pemecahanmasalah-matematis-siswa-smp.html

Hiebert, J et al. (1996). Problem Solving as a Basis for Reform in Curriculum and Instruction: The Case of Mathematics. Educational Researcher, 25(4), 12-21. Retrieved from https://www.researchgate.net/publication/243779916_Problem_Sol ving_as_a_Basis_for_Reform_in_Curriculum_and_Instruction_The _Case_of_Mathematics

Hendriana, Heris \& Soemarmo, Utari. (2014). Penilaian Pembelajaran Matematika. Bandung: Refika Aditama

Huda, Ummul. (2016). Analisis Habit of Thinking Interdependently (HTI) Siswa SMP dalam Pembelajaran Kooperatif. Ta'dib, 19(1), 15-22. Retrieved from http://ecampus.iainbatusangkar.ac.id/ojs/index.php/ takdib/article/download/447/435

Kaur, Berinderjeet. (1997). Difficulties with Problem Solving in Mathematics. The Mathematics Educator, 2(1), 93-112. Retrieved from https://repository.nie.edu.sg/bitstream/10497/132/1/TME-2-193.pdf 
Kim, Sharon et al. (2019). Improving 21st-century Teaching Skills: The Key to Effective 21st-century learners. Research in Comparative \& International Education, 14 (1), 1-19. Retrieved from https://www.researchgate.net/publication/262091816_Learning_21s t-Century_Skills_Requires_21st-Century_Teaching

McGregor, Debra. (2007). Developing Thinking Developing Learning: A Guid to Thinking Skills in Education. New York: Open University Press

Mullis, et al. (2012). TIMSS 2011 International Results in Mathematics. U.S.: International Association for The Evaluation of Educational Achievment

Ninik, Hobri \& Suharto. (2014). Analisis Kemampuan Pemecahan Masalah untuk Setiap Tahap Model Polya dari Siswa SMK Ibu Pakusari Jurusan Multimedia pada Pokok Bahasan Program Linier. Kadikma, 5(3), 61-68. Retrieved from https://jurnal.unej.ac.id/index.php/kadikma/article/view/1374

Pehkonen, Erkki. (2011). Problem Solving in Mathematics Education in Finland. CEPS Journal. 3(4). 9-23, Retrieved from https://files.eric.ed.gov/fulltext/EJ1129533.pdf

Qudsy, Saifuddin Zuhri \& Fawaid, Ahmad. (2012). Cooperative learning Metode, Teknik, Struktur, dan Model Penerapan. Yogyakarta: Pustaka Pelajar

Rusman. (2010). Model-Model Pembelajaran Mengembangkan Profesionalisme Guru. Jakarta: PT. Raja Grafindo Persada

Silver, Edward A. (2009). Teaching and Learning Mathematical Problem Solving: Multiple Research Perspectives. New York: Routledge

Stanic, G., \& Kilpatrick, J. (1989). Historical perspectives on problem solving in the mathematics curriculum. In R.I. Charles, \& E.A. Silver (Eds.), The teaching and assessing of mathematical problem solving (pp. 1-22). Reston, VA: National Council of Teachers of Mathematics

Ulvah, Shovia \& Afriansyah, Ekasatya Aldila. (2016). Kemampuan Pemecahan Masalah Matematis Siswa ditinjau melalui Model Pembelajaran SAVI dan Konvensional. Jurnal Riset Pendidikan, 
14 | Rahmadeni : Pengembangan Kemampuan Pemecahan Masalah Matematis ...

2(2), 142-153. Retrieved from http://hikmahuniversity.ac.id/ lppm/jurnal/2016/text07.pdf 